DOI: 10.33310/2518-7813-2019-65-2-32-35

УДК 378.1

\title{
Наталя БОБРИШЕВА
}

кандидат педагогічних наук, доцент кафедри англійської мови в судноводінні

Херсонської державної морської академії, м. Херсон, Україна

\section{МОДЕЛЮВАННЯ КОМУНІКАТИВНИХ СИТУАЦІЙ

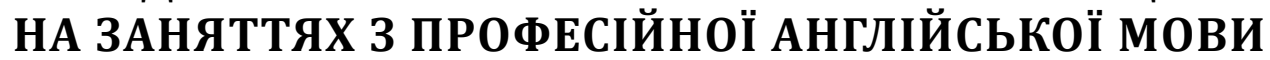 В МОРСЬКИХ НАВЧАЛЬНИХ ЗАКЛАДАХ}

\begin{abstract}
У статі окреслені засоби моделювання комунікативних ситуацій на заняттях з професійної англійської мови майбутніх морських офіцерів з огляду на полікультурну складову їх професійної діяльності. Автор виділяє принципи моделювання комунікативних ситуацій на заняттях з професійної англійської мови, яким викладач має слідувати: принџип неперервності, принцип професійної спрямованості, прин ции діалогічності, принцип комплексності. Розкриваються приклади моделювання комунікативних си туацій на різних курсах з урахуванням їх рівня володіння англійської мови. Автор робить висновок, що моделювання комунікативних ситуацій допомагає будувати ефективну модель спілкування між пред ставниками різних національностей і культур, вирішуючи міжкультурні конфлікти.

Ключові слова: комунікативні ситуації, полікультурний екіпаж, професійна діяльність, принципи, форми, методи.
\end{abstract}

Перехід до компетентнісної, особистісно орієнтовної освітньої парадигми в другій половині XX століття є наслідком процесів глобалізації та інтеграції всіх сфер людської діяльності, які відбуваються у світовому співтоваристві. У зв'язку з цим з'являється тенденція світової спільноти розвиватися в рамках полікультурності, рівності всіх культур, толерантного відношення до культурних особливостей інших національностей. Зокрема, у численних проектах ЄС, ради Європи, ЮНЕСКО закладені принципи «багатомовності», «мультилінгвізму» і «полікультурності», що проголошені в якості першорядних для систем національної освіти.

У таких умовах виникає соціальна потреба у формуванні «людини культури», полікультурнограмотного майбутнього морського офіцера, який поєднує в собі високий рівень професійних знань, умінь і навичок з орієнтацією на етнокультурні духовні цінності, толерантність і здатність до міжкультурного діалогу. Ця вимога пов'язана, в першу чергу, з тим, що професійна діяльність морського спеціаліста відбувається в умовах полікультурного середовища, тобто у складі багатонаціонального екіпажу на судні під іноземним прапором, а також під час виконання професійних обов'язків у портах різних країн, спілкування $з$ представниками портових служб, радіозв'язку 3 іншими судами. Тому для ефективної професійної взаємодії у полікультурному середовищі морський спеціаліст має володіти не тільки англійською мовою, знання якої $є$ обов'язковою вимогою для праці на іноземних судах, а й здатний орієнтуватися у такому полікультурному середовищі, взаємодіяти з представниками інших культур, створювати атмосферу співробітництва, поваги під час керівництва багатонаціональним екіпажем. Таким чином моделювання комунікативних ситуацій на заняттях 3 професійної англійської мови допоможе студентам морських навчальних закладів бути готовим до майбутньої професійної діяльності у полікультурному середовищі.

Теоретичне осмислення проблеми впровадження комунікативних ситуацій у процес вивчення іноземних мов відображено у працях вітчизняних і зарубіжних науковців Н. Гальскова, Ж. Горіна, К. Можаєва, Л. Морська, С. Кожушко, П. Сисоєв, О. Тарнопольський, В. Топалова. Різні аспекти питання професійної підготовки фахівців морського транспорту розкрили Г. Бокарєва, Г. Варварецька, В. Дулін, Т. Коестер, С. Козак, М. Кулакова, Е. Нобл, Д. Мелінг, М. Прогуляки, I. Сокол, В. Фадєєв, Я. Хорк та ін.

Проте аналіз наукових досліджень дає підстави стверджувати, що проблема моделювання комунікативних ситуацій на заняттях з професійної англійської мови в морських навчальних закладах на ще недостатньо досліджена. Тому метою статті $\epsilon$ окреслення засобів моделювання комунікативних ситуацій на заняттях з професійної англійської мови майбутніх морських офіцерів з огляду на полікультурну складову їх професійної діяльності.

На сучасному етапі модернізації професійної підготовки фахівців та впровадження компетентнісного підходу морський спеціаліст має володіти не тільки високим рівнем знань та вмінь, але й бути готовим до співпраці з полікультурним екіпажем. У цих умовах студент вже під час професійної підготовки у вищому морському навчальному закладі має можливість підготуватись до міжку- 
льтурної комунікації на заняттях 3 професійної англійської мови засобами моделювання комунікативних ситуацій, які б відображали реалії майбутньої професійної діяльності з огляду на полікультурний екіпаж. Уявлення про культуру, правила поведінки в полікультурному середовищі, вивчення ціннісних орієнтацій представників інших культур є однією з основних вимог до професійної освіти морських офіцерів. Конфлікт культур, який визначається відмінностями в історичному, соціальному і політичному розвитку, може призвести до професійних помилок, соціальних конфліктів і, як наслідок, - до виникнення аварійних ситуацій на судні. Тому професійна підготовка морських спеціалістів повинна бути спрямована на формування їх готовності до професійної діяльності у полікультурному середовищі.

Цінними для нашого дослідження $є$ наукові висновки О. Олсена (0. Olsen) про культурну різницю у виявах особистісних якостей старших офіцерів на торгових судах. В результаті експерименту науковець визначив, що представники Азії капітани, старші помічники, старші механіки, другі механіки характеризуються високим рівнем вияву позитивних особистісних якостей (емпатія, самоконтроль, гнучкість, емоційна рівновага), які ефективні під час професійної діяльності у полікультурному екіпажі, ніж представники Західної та Східної Європи, які виявились не готовими до вирішення міжкультурних конфліктів, саме тому вони потребують проходження спеціальних курсів полікультурної підготовки.

Розкриваючи питання підготовки морських спеціалістів, дослідниця Е. Нобл (A. Noble) наголошує, що навчання культурної обізнаності майбутніх морських фахівців сприятиме отриманню вмінь та навичок під час міжкультурного спілкування у полікультурному екіпажі $[279,26]$.

Обгрунтовуючи у своїх численних працях аспекти вивчення морської англійської мови як офіційної мови морських спеціалістів, англійський методист В. Шорт (V. Short) наголошує, що під час навчання цієї мови майбутні морські фахівці можуть отримувати знання з полікультурної підготовки $[285,8]$.

Ми повністю погоджуємось 3 думкою О. Луценко, яка розкриваючи особливості навчання студентів морських спеціальностей у Нідерландах, підкреслює важливість кооперації між морськими установами, університетами, морськими компаніями щодо підготовки морських спеціалістів до роботи у полікультурному екіпажі, як важливої умови комплексності професійної підготовки $[273,27]$.

Надзвичайно важливими у контексті нашого дослідження є доробки Р. Гришкової, яка у своєму науковому доробку розкриває питання формування іншомовної соціокультурної компетенції студентів нефілологічних спеціальностей у процесі їх фахової підготовки. Науковець наголошує на важливості формування означеної компетентності, зміст якої складається з інтегрованих професійних соціокультурних знань, що реалізуються у практичних навичках комунікативної поведінки, та фонових знань (сукупність слів та їх значень, необхідних для успішної комунікації з представником іншої культури). Іншомовна соціокультурна компетенція розглядається вченою в контексті Програми 3 англійської мови для професійного спілкування та принципів інтерактивності, інтеграції, контекстуалізації, інтернаціоналізму, плюрилінгвізму, раннього професійного спрямування навчання іноземної мови $[70,143]$. Характеризуючи мовну освіту в Україні як полікультурний, полілінгвальний простір, вона обгрунтовує мету формування іншомовної соціокультурної компетенції - розуміння студентами нефілологічних спеціальностей різниці між рідною та «чужою» культурами та подолання соціокультурних розбіжностей під час професійного спілкування. Досягнення означеної мети, на думку Р. Гришкової, можливо через введення соціокультурних понять 3 опорою на порівняння, приклади та свідоме вживання їх в спонтанному мовленні в нестандартних ситуаціях та використання під час навчання за спеціальним підручником, який побудований 3 урахуванням принципів «полілога культур» та культурогологічного підходу до навчання іноземних мов $[70,111]$.

Ми повністю погоджуємося із дослідницею С. Тер-Мінасовою, яка наголошує, що головна мета вивчення іноземних мов як засобу комунікації, полягає в тому, що мови повинні вивчатися в нерозривній єдності зі світом і культурою народів, що говорять на цих мовах $[229,98]$.

На нашу думку під час моделювання комунікативних ситуацій на заняттях з професійної англійської мови викладач має слідувати таким принципам:

- принцип неперервності, який є системотворчим чинником у поступовому впровадженні системи знань, вмінь і навичок про сутність та специфіку досліджуваного утворення з першого по п'ятий курси, у подальшій післядипломній освіті, сприяючи цілісності цього процесу;

- принцип професійної спрямованості, сутність якого полягає в орієнтації завдань, змісту, методів і форм організації навчально-виховного процесу на майбутню професію фахівців

- принцип діалогічності, який зумовлює сферу діяльності майбутніх морських офіцерів: спілкування з членами екіпажу, проведення брифінгів, віддавання наказів тощо, формуючи 
теоретичний та професійний розвиток майбутніх фахівців, він сприяє суб'єкт-суб'єктним зв'язкам, у результаті чого курсанти оволодівають уміннями та навичками враховувати позицію співрозмовника, організовувати та здійснювати співпрацю з членами екіпажу, адекватно сприймати та передавати інформацію;

- принцип комплексності, який полягає у взаємозв'язку складових компонентів навчальновиховного процесу, забезпечуючи цілісність впливу на формування особистості майбутнього морського офіцера, адже під впливом викладання різних навчальних циклів дисциплін у курсантів формується готовність до професійної діяльності у полікультурному середовищі.

Найбільш ефективними для моделювання та проведення комунікативних ситуацій є такі форми i методи роботи, які б спонукали студентів до більш активного спілкування, це стосується таких занять, як заняття 3 використанням мозкового штурму, дискусійного обговорення професійно важливих проблем, практичні заняття з використанням методу проектів, навчання у співпраці, створення проблемних ситуацій, ділових ігор, професійно спрямованих відеофільмів, підготовка мультимедійних презентацій, віртуальних екскурсій, Інтернет-технологій, мультимедійних посібників.

Окреслимо більш детально приклади моделювання комунікативних ситуацій. Так, на першому курсі викладач може створювати комунікативні ситуації при вивченні повсякденних тем. При вивченні теми «Їжа» студентам можна запропонувати уявити ситуацію, коли український повар на судні обговорює меню із корейським капітаном.

На 2 курсі під час вивчення теми «Лоцман» викладач пропонує імітаційно-рольова гра «Лоцман на навігаційному містку», де лоцман представник країни Японії, а капітан та команда український екіпаж та відповідні ситуації нерозуміння один одного: під час визначення напрямів та шляху у порту, попередньої прокладки шляху судна з урахування течії та вітру.

У темі «Швартування» розглядаються причини нерозуміння наказу українського офіцера китайським матросом щодо перевірки стану швартових.

Під час занять із старшими курсами викладач вже може ускладнювати комунікативні ситуації та використовувати вправи, типу мозкового штурму (brainstorming), вибору варіантів правда чи брехня (true/false statements), а також вибору правильного варіанту (matching) з подальшим обговоренням у групах чи парах. Курсантам можуть пропонуватись розіграти різні ситуації, які можуть виникнути під час професійної діяльності:

1. Second Officer asks Filipino AB to check the condition of pilot ladder without explaining details. $A B$ answers YES and Second Officer thinks that the order is clear. Later it occurred that AB didn't do it.

2. It's Christmas and Filipino Captain asks you to join the celebration and offers a desert. Second Officer refuses. After that case Captain starts to be aggressive to the Second Officer.

3. Filipino Captain says HI to Second Officer, who came to the bridge, but Second Officer doesn't answer, because he talks to another Officer. After that case Captain starts to be aggressive to the Second Officer.

На 4 курсі під час вивчення розділу «Менеджмент суднової команди на навігаційному містку» викладач може формувати критичні вміння під час комунікативних ситуацій засобами кейсситуацій. Так, наприклад, студентам пропонується розглянути таку кейс-ситуацію: під час вахти на навігаційному містку український офіцер пропонує філіппінському матросу зробити перерву, однак матрос розуміє цей наказ, як взагалі не приходити на вахту, що і робить.

Отже, моделювання комунікативних ситуацій з огляду на полікультурну складову підготовки майбутніх морських офіцерів сприяють знайомству з міжкультурними особливостями у міжособистісних відносинах представників різних національностей. Така форма роботи, як свідчать теорія та практика, допомагає будувати ефективну модель спілкування між представниками різних національностей і культур, вирішуючи міжкультурні конфлікти. Практика міжкультурного спілкування свідчить, що знання лексико-граматичної системи іноземної мови ще не гарантують досягнення взаєморозуміння, бо культурні відмінності членів полікультурного екіпажу можуть призвести до непорозуміння або навіть до конфлікту та «культурного шоку».

\section{Списоквикористаних джерел}

1. Гришкова Р. Формування іншомовної соціокультурної компетенції студентів нефілологічних спеціальностей : монографія, Миколаїв: МДГУ ім. П. Могили, 2007. 424 с.

2. Луценко 0. Making the mixwork. Tekegraph, September 2010. 27 p.

3. Тер-Минасова С. Язык и межкультурная коммуникация. Москва: Слово, 2000. 624 с.

4. Noble A. Make the most of diversity. Telegraph. June 2011.26 p.

5. Olsen 0. Cultural differences in emotional intelligence among top officers on board merchant ships. Academy of Management Executive, Feb 2000, Vol. 14 Issue 1, P. 79 - 95.

6. Short V. Maritime English valuing a common language Seaways. 2006. P. 2 - 12. 


\section{References}

1. Grishkova R. 0. (2009) Formuvannya inshomovnoyi sotsiokulturnoyi kompetentsii studentiv nefilologichnih spetsialnostey [Formation of foreign technical specialized students' crosscultural competence] : monografiya. Mikolayiv. (In Ukrainian)

2. Lutsenko 0. (2010) Making the mixwork Tekegraph. September. (in English)

3. Ter-Minasova S. (2000) Yazyik i mezhkulturnaya kommunikatsiya. [Language and crosscultural competence]. M. : Slovo. (In Russian)

4. $\quad$ Noble A. (2011) Make the most of diversity.Telegraph. June. № 10 (in English)

5. Olsen 0. (2000) Cultural differences in emotional intelligence among top officers on board merchant ships. Academy of Management Executive, February 2000, Vol. 14, Issue 1. (in English)

6. Short V. (2006) Maritime English valuing a common language. Seaways, Vol. 2 (in English)

Наталя Бобришева. Моделирование коммуникативных ситуаций на занятиях с профессиональной английского языка в морских учебных заведений

В статье обозначены средства моделирования коммуникативных ситуаций на занятиях по профессиональному английскому языку будущих морских офищеров, учитывая поликультурную составляющую их профессиональной деятельности. Автор выделяет принципы моделирования коммуникативных ситуаций на занятиях по профессиональному английскому языку, которые преподаватель должен следовать: принцип непрерывности, принцип профессиональной направленности, принцип диалогичности, принцип комплексности. Раскрываются примеры моделирования коммуникативных ситуаций на различных курсах с учетом их уровня владения английского языка. Автор делает вывод, что моделирование коммуникативных ситуаций помогает строить эффективную модель общения между представителями разных национальностей и культур, решая межкультурные конфликты.

Ключевые слова: коммуникативные ситуации, поликультурный экипаж, профессиональная деятельность, принципы, формы, методы.

Nataliya Bobrysheva. Simulation of communicative situations during the professional English classes in maritime educational institutions

The article identifies tools for modeling communicative situations during the professional English classes of future maritime officers, considering the multicultural component of their professional activities. The author identifies the principles of modeling communicative situations during the professional English classes, which the teacher should follow: he principle of continuity, which is a system-creating factor in the gradual introduction of the knowledge system, skills and abilities of the essence and specificity from the first to the fifth courses, in further postgraduate education, contributing to the integrity of this process; the principle of professional orientation, the essence of which is the orientation of the tasks, content, methods and forms of organization of the educational process for the future specialists' profession; the principle of dialogue that determines the scope of future maritime officers: communication with crew members, briefing, giving orders, etc., forming the theoretical and professional development of future specialists; it facilitates subject-subject connections, resulting in cadets mastering skills and abilities to take into account the position of the interlocutor, to organize and cooperate with the crew members, to adequately perceive and transmit information; the principle of complexity, which consists in the interconnection of the components of the educational process, ensuring the integrity of the influence on the formation of the personality of the future marine officer, as under the influence of studying various disciplines of cadets formed readiness for professional activity in the multicultural environment. Author gives examples of modeling communicative situations for various courses, taking into account their level of English. For the senior maritime students, the teacher may give more complicate communicative situations and use exercises such as brainstorming, choosing true/false statements, and choosing the right option (matching) with subsequent discussion in groups or pairs. The author concludes that the modeling of communicative situations helps to build an effective model of communication between representatives of different nationalities and cultures, solving intercultural conflicts.

Keywords: communicative situations, multicultural crew, professional activity, principles, forms, methods. 